\title{
THE DUTIES OF A TRUSTEE WITH RESPECT TO DEFAULTED MORTGAGE INVESTMENTS
}

\section{Parker Bailey $\dagger$ and Charles Keating Rice $\dot{\dagger}$}

The prolonged stagnation of the realty market continues to create difficulties of adjustment between legal precepts and economic reality. The shrinkage in land values, accompanied by a flood of mortgage foreclosures, has resulted in the emergence of a vast number of troublesome questions, of pressing significance to lawyers occupied with real estate matters and to fiduciaries charged with trust administration. The present discussion is suggested, in particular, by the grave concern of fiduciaries over the problems consequent upon the foreclosure of defaulted trust mortgages.

Mortgages have long been recognized as a proper medium for trust funds, ${ }^{1}$ and until recent years trustees generally have taken frequent advantage of their availability for investment. Under favorable business conditions the ready marketability both of mortgages and of mortgage participations has made such investments especially desirable. One may doubt whether they would have met with such continued favor had the trustees foreseen the numerous ways in which the administration of them would be complicated by unfavorable business conditions.

In normal times it was only occasionally necessary for a trustee to foreclose a trust mortgage ; now it has become an almost daily occurrence

†A.B., I923, Yale University; LL.B., I934, Cornell University; member of the New York Bar.

$¥$ A. B., I932, LL. B., I934, Cornell University ; member of the New York Bar.

The authors are indebted to Mr. Adrian D. Stevenson, of the New York Bar, for many helpful suggestions and comments.

I. Bishop v. People's Bank \& Trust Co., 2r8 Ky. 508, z9r S. W. 718 (I927) ; Denton v. Sanford, I03 N. Y. 607, 9 N. E. 490 (I886); In re Gouldey's Estate, 20I Pa. 49I, 5I At1. 3I5 (1902). Such investments are now generally sanctioned by statute. See ConN. GEN. STAT. (I930) \$ 4836; Fla. Laws I93I, c. I5064; Idaho Laws I929, c. 20; ILI. REv. STAT. (SmithHurd, I930) § 32, c. I48; Iowa Code (I93I) § I2772; Kan. Rev. Stat. ANN. (I923) \$\$ 40307 ; Ky. Stat. (Carroll, 1930) § 4706; La. Gen. Stat. (I932) § 589; Mass. Laws 1932, c. I72, \$ 5 I; Minn. Gen. StaT. (I927) \$77I4; N. Y. DECEDEnT Estate LAW (I9I6) \$ III; N. Y. Personal Property Law (IgI7) \& 2I; Ohio Probate Code (I93I) \& I0506-4I; Ore. Code ANN. (1930) \$22-I214, as amended by Ore. Laws I931, c. 278; PA. StAT. ANN. (Purdon, I930) tit. 20, §80I; S. C. CoDe (I932) § 905I; S. D. Comp. Laws (I929) § 9049; Tenn. Pub. Acts I93I, c. I00; TEx. REv. Crv. CoDE (Vernon, I928) art. 5II; Vt. Public Laws rg33, §6706; VA. CODE ANN. (Michie, I930) \$543I; WASH. Comp. STAT. (Remington, I922) § 3255 ; W. VA. CoDe (193I) c. 44, art. 6, § 2 ; WIS. Stat. (I93I) §23I.32; Wyo. Rev. Stat. (I93I) § I0-305. See also Gouley, Real Estate Mortgage Bonds as Trust Investments (1935) 83 U. OF PA. L. REV. 953.

2. The absence, in normal times, of case law involving the problems now under discussion is doubtless due to the fact that the trustee is seldom forced to bid in the property himself. Indeed, it is his duty to dispose of the property to others unless it is impossible to obtain a fair price for it, for as a general rule, in the absence of statute or authority given by will, investment of trust funds in lands is a breach of trust. Butler v. Butler, I64 III. I7I, $45 \mathrm{~N}$. E. 426 (I896) ; Jordan v. Jordan's Estate, III Me. I24, 88 Atl. 390 (IgI3); Zimmerman v. Frailey, 70 Md. 56I, I7 Atl. 560 (I889); Smith v. Robinson, 83 N. J. Eq. 384, 90 At1. I063 (Ch. I9I4); In re A hrend's Estate, 3 N. J. Misc. 746, I30 Atl. 219 (Orph. Ct. I925), app. dismissed, 99 N. J. Eq. 328, I32 At1. 758 (Prerog. I926); In re Leonard's Will, 202 Wis. II7, 230 N. W. 715 (1930). See 3 BogerT, Trusts aND TRUSTEES (I935) $§ 678$. 
for him to foreclose in order to liquidate the investment. Such a foreclosure is amply supported by authority when necessary to preserve or to protect the trust estate, ${ }^{3}$ but out of it arise the difficulties of administration which embarrass the trustee. Frequently he is compelled, in the absence of other bidders, to bid in the property himself. ${ }^{4}$ The resulting questions of the allocation of carrying charges during the period while the property is being held by the trustee as owner, of the disposition of income received during the carrying period, and of apportionment of the proceeds resulting from the final liquidation of the investment, are matters which heretofore the trustee has only at intervals been called upon to face. Now they are his immediate and principal concern.

More than thirty years ago a surrogate, confronted with the necessity of offering a practicable solution for problems of this very type, declared:

"There must be some legal policy to govern trustees in the administration of estates, because such a situation as now presented, the investment on bond and mortgage, the foreclosure, the buying in, the carrying until a favorable time for a sale, and the subsequent sale at a profit, is in the business of testamentary trustees a matter of daily occurrence. Trustees are entitled to have pointed out a rule which they can follow without fear of having their conduct challenged. . . ." 5

Three decades of judicial consideration of the various questions, recurring in each depression so to "challenge" trustees, have failed to bring widespread or decisive approval of helpful rules from courts of last resort.

In the management and ultimate disposition of any trust investment there is necessarily some conflict of interests between life tenant and remainderman. In the case of defaulted trust mortgages, however, this conflict is accentuated by the frequency with which specific problems of

3. Lockman v. Reilly, 95 N. Y. 64 (1884); Valentine v. Belden, 20 Hun 537 (N. Y. 1880); Jessup \& REDFIELd, LAW aNd PRACTICE IN the SurRogates' Courts (3d ed. I93o) $\$ 764$.

4 "The plaintiff, as the administrator . . . , became possessed of the said bond and mortgage as a part of her personal estate, and was authorized to collect the money due thereon by the foreclosure of the mortgage, and it became his duty to resort to such remedy when payment was neglected or refused. To save the estate from loss it was also his right and duty to bid in the premises at the sale, and to hold the same until they could be disposed of by him for the benefit of the estate which he represented." Ingalls, J., in Valentine v. Belden, 20 Hun 537, 54I (N. Y. I880). To the same effect: In re Bellah, 8 Del. Ch. 59, 67 Atl. 973 (Ch. I896); In re Baker, 8 Del. Ch. 355, 68 Atl. 449 (Ch. I899) ; 3 Bogerr, TRUSTs

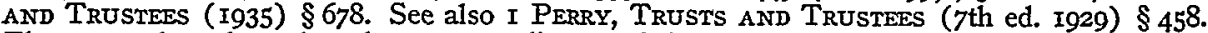
The trustee is under a duty, however, to dispose of the property as soon as possible. Furniss v. Cruikshank, I9I App. Div. 450, r8I N. Y. Supp. 522 (Ist Dep't I920), modified on other grounds, 230 N. Y. 495 , I30 N. E. 625 (Ig2r), 23 I N. Y. 550, I32 N. E. 884 (I92I); Willis v. Holcomb, 83 Ohio St. 254, 94 N. E. 486 (IgIr).

In New York, since I933 banking corporations which act as trustees have been specifically empowered to purchase real estate after foreclosure of a defaulted mortgage held by them as trustees. N. Y. Real Property Law (rgI7) \& IIg. See also N. Y. Banking Law (I9I6) § I88 (7), as amended by N. Y. Laws I933, c. 323; N. Y. DECEDENT ESTATE LAW (I9I6) § III (3), (4).

5. Silkman, S., in Matter of Marshall, 43 Misc. 238, 242, 88 N. Y. Supp. 550, 552-553 (Surr. Ct. 1904). 
allocation of income and expenses arise, and by the lack of rules definitely settling the respective rights of these parties. It is the purpose of this discussion to consider the differing contentions of these parties, and to see in what manner the trustee may resolve or compromise their conflicting interests while safeguarding his own position as a fiduciary subject to possible surcharge in the event of misapprehension of the proper rule.

\section{Disposition of the Ultimate Proceeds From Sale of Foreclosed Trust Properties}

Chronologically the last, yet perhaps the most important problem which the trustee must meet in the sequence of events after foreclosure of a defaulted trust mortgage, is the distribution of the proceeds remaining from the final sale. The sale may result in a real profit; that is, a surplus over the amount of the accrued unpaid interest, the original investment, and the expenses of liquidation. More often, under present conditions, it will result in a loss, in that the final proceeds will be less than the total amount of these items. In the latter event, the contention is frequently made by the remainderman that since the amount of the original investment cannot be restored, he is entitled to the full proceeds of the sale. The life tenant, on the other hand, complains that this solution of the difficulty thrusts the entire burden of the loss upon him, and contends that in this, as in other situations ${ }^{6}$ in which a loss is apportioned in some manner between life tenant and remainderman, there should be an equitable distribution of the burden.

Apportionment, both of income and of expenses, is a well-known phase of trust administration. It is elementary that in the distribution of trust funds, income goes to the life tenant, and principal, or corpus, to the remainderman. Yet frequently, in computing the net income due to the life tenant, it must be determined whether a given necessary expen-

6. The doctrine of equitable conversion, as it is invoked in the field of trusts of unproductive real property, represents an attempt by the courts to divide fairly the proceeds of sale between capital and income. Where a testator establishes a trust of unproductive real property, income to the life tenant and remainder over, with a mandatory power of sale in the trustee, it is generally held that the life tenant is entitled to a share of the ultimate proceeds of sale, which share is to be determined as though the property had been immediately converted into a productive investment at the testator's death. A sum is computed which, invested on the date of the testator's death at the rate of interest normal for trust investments generally, could have produced the amount actually realized. This sum goes to principal, the balance to income. See Lawrence v. Littlefield, 215 N. Y. 56I, I09 N. E. 6II (I9r5) ; Furniss v. Cruikshank, 230 N. Y. 495, I30 N. E. 625 (I92I); Matter of Jackson, 258 N. Y. 28I, 179 N. E. 496 (1932). Cf. Matter of Satterwhite, 262 N. Y. 339, I86 N. E. 857 (I933). The will must evidence an intent for an immediate conversion, however, or the doctrine will not apply. Creed v. Connelly, 272 Mass. 24I, I72 N. E. I06 (I930). But see Equitable Trust Co. v. Kent, II Del. Ch. 334, xor Atl. 875 (I9I7). The doctrine has never been held to apply to a vested remainder subject to an overriding life estate. See In re Thirkield's Estate, I52 Misc. 280, 273 N. Y. Supp. 856 (Surr. Ct. N. Y. Co. I934); Note (I935) 35 Col. L. Rev. 306. See generally Restatement, TRUSts (I935) $\$ \$ 240$, 24I. 
diture should be deducted wholly from income or from principal, or in some manner from both. When the expenditure is calculated to benefit the interests of both parties, it is only fair that they should share it, and it is generally so held. Similarly, it is argued, when there is a realization of funds following a period of default which has caused loss to both parties, there should be an apportionment of the funds realized, since neither was responsible for the deficit. The argument is carefully phrased by Vice-Chancellor James in a well-known English case:

"The true principle in all these cases is, that neither the tenant for life nor the remainderman is to gain an advantage over the otherneither is to suffer more damage in proportion to his estate and interest than the other suffers-from the default of the obligor. The two must share the loss in the same way as they would have shared it had it occurred when they first became entitled in possession to the fund." 7

Or, as Mr. Justice Cullen more picturesquely put the matter in a New York Appellate Division case: "Why should the life tenant fast for twentyfive years that the remainderman may feast at the end of that period? Why should each not have exactly his own, so far as it is possible to ascertain it?" 8

The case law on the question whether there should be such an apportionment of the proceeds of sale between capital and income is largely confined to cases in which the ultimate sale resulted in a loss. For this reason, and in view of the additional fact that the question of apportionment when the sale results in a profit is complicated by the seemingly conflicting rule that accretions to a trust fund normally go to principal, it has seemed advisable to discuss separately the apportionment of loss and of profit.

\section{A. Apportionment When Sale Results in Loss}

The development of the apportionment doctrine in connection with the sale of foreclosed trust properties may be conveniently traced through a series of cases in each of which the sale resulted in a loss. Students and writers in this field have been inclined to attribute the formulation and growth of the doctrine to certain early English cases. As a matter of fact, the first reported case allowing the life tenant a share in the ultimate proceeds of sale is apparently an early and seldom-cited New York case, Roosevelt $v$. Roosevelt. ${ }^{9}$ In this case, the testator owned at his

7. Cox v. Cox, L. R. 8 Eq. 343, 344 (1869).

8. Matter of Rogers, 22 App. Div. $428,436,48$ N. Y. Supp. I75, I8I (2d Dep't I897), aff'd, I6I N. Y. 108, 55 N. E. 393 (1899).

9. 5 Redf. Surr. 264 (N. Y. Surr. Ct. I88I). For a fuller statement of the facts involved in this case, see the earlier case of Scovel v. Roosevelt, 5 Redf. Surr. I2I (N. Y. Surr. Ct. I88I). 
death a judgment of foreclosure for $\$ 8,595.22$, and a mortgage on which $\$ 5,7$ II.66 was due. On the sale of the judgment the executor bid in the premises, and he subsequently sold them for $\$ 7,530.15$, which sum he carried to the account of principal, the life tenants receiving no income until the receipt of the proceeds of sale-a period of nearly three years. On foreclosure of the mortgage, the executor received as net proceeds the sum of $\$ 6,147.91$, of which $\$ 5,7$ II. 66 , the amount due at the date of the testator's death, was carried on the capital account. The executor obviously felt that instead of apportioning the proceeds, he should restore the amount of the original investment before allocating anything to income. Upon a subsequent reference, the referee apportioned the amount so received between capital and income according to the rule that the "principal sum" is that sum which, together with interest accruing thereon at the rate of five per cent per annum from the date of the testator's death, would produce, by the time when the proceeds were actually received, the total amount of such proceeds. The life tenant thereupon entered objections to the application of this rule, despite the fact that no precedent existed for the allocation of any part of the proceeds to income. Surrogate Calvin, however, confirmed the report of the referee, approving the rule applied, upon the authority of the English case of Cox v. Cox. ${ }^{10}$

The Cox case did not involve a mortgage foreclosure. By a marriage settlement an obligor covenanted that there would be paid three months after his death a fund to trustees, in trust for his widow for her life, with remainder over to her children, with interest at the rate of five per cent per annum from the date of his death until payment. Several years after his death, assets were recovered which even then were insufficient to fulfill the covenant and bond. Since the assets were insufficient to pay both the principal and interest on this covenant, they were apportioned between the life tenant and the remainderman. The life tenant was given that sum which, invested on the day of the obligor's death at four per cent per annum, would have amounted, with such interest, to the sum finally recovered.

The case most frequently referred to as the one in which the doctrine of apportionment in the field of trust mortgages originated is another English case, In re Moore. ${ }^{11}$ In this case, $\mathfrak{f 8 , 0 0 0}$ was invested in the trust mortgage. The interest was not regularly paid, and the arrears amounted to $£_{53} 6$ when the property was foreclosed. $\mathfrak{E}_{7,900}$ was realized on the sale. The court held that the $\mathfrak{E}_{7,900}$ should be apportioned between principal and income in the ratio which $£ 8,000$ bore to $£ 536$.

The further development of the equitable doctrine of apportionment upheld in the Roosevelt and Moore cases was seemingly arrested by the New 
York case of Farmers' Loan \& Trust Co. v. Hall. ${ }^{12}$ The qualification, "seemingly," is used advisedly, for the court did not question the validity of the Roosevelt rule or its application in a proper case. The weakness of the Hall case, from the point of view of an advocate of the apportionment doctrine, is that upon facts seeming to call for an application of the doctrine, the court refused to allow any apportionment whatever. In this case, the testator left one-half of the residue of his estate to trustees, to apply the income thereof to the use of his daughter during her life, and at her death to convey the share to her children, or to his grandchildren (the children of the testator's son) if she left no children surviving her. The executors invested $\$ 37,000$ in a mortgage in 1876 . The mortgage was foreclosed by the surviving trustee, who in 1879 bought in the property for $\$ 25,000$. There had also been invested $\$ I I, 000$ in another mortgage, which was foreclosed, and in 1880 also bought in by the trustee for $\$ 7,500$. The first mentioned property was subsequently sold for $\$ 45,000$, and the other property for $\$ 5,250$. The general question before Surrogate Coffin was the distribution of the funds on hand. The total sum invested in the mortgages was $\$ 48,000$. The total expenses were $\$ 4,680.69$. The total amount received for the properties on the subsequent sales was $\$ 50,250$, which was a sum slightly less than the total of the original investments plus the expenses of foreclosure, maintenance, etc.

It was contended by the life tenant, the testator's daughter, that some part of this sum should be allocated to income. Surrogate Coffin, however, held that the entire proceeds were to be regarded as corpus, since they were tantamount to a restoration of the original investment in the mortgages. After discussing the rights of the parties to the fund, he concluded:

"No reason is discovered for going into any calculation as to what portion of the fund to be distributed is to be regarded, as capital, and what portion income, first, because there is no sum to be considered in the light of income, and no question as between a life beneficiary and remainderman, and second, because the loss or gain, occurred on loans made by the trustees in the course of administration, in making investments and not by the decedent. The case of Roosevelt v. Roosevelt ( 5 Redf., 264) is, therefore, not in point." 13

Neither of the reasons given by the learned surrogate for his refusal to apportion is especially persuasive. The statement that "there is no sum to be considered in the light of income", and that therefore there should be no apportionment, begs the question entirely, since whether or not there was income to allocate was the very issue before the court. And since the life tenant was insisting upon a distribution to income, it does not seem that the

12. 5 Dem. Surr. 73 (N. Y. Surr. Ct. I887).

I3. $I d$. at 80 . 
issue should have been summarily disposed of by the assertion that there was "no question as between a life beneficiary and remainderman." 14

The second reason given by Surrogate Coffin, namely, that the rule of apportionment is to be applied only to an investment made by the testator or settlor, emphasizes a difference in the cases which would seem to be of little practical importance. Since the principle of apportionment is calculated to relieve the life tenant of an undue burden of loss, it should make no difference whose investment resulted in the eventual deficit. Indeed, conditions entirely beyond the control of any investor, either settlor or fiduciary, may cause the investment to become unprofitable. ${ }^{15}$

The Hall case did not have as deterrent an effect as it might conceivably have had upon the evolution of the doctrine of apportionment, either in New York or elsewhere; in fact, the case has been almost entirely ignored in subsequent decisions. ${ }^{16}$ Within a few years after the Hall decision the New Jersey Court of Chancery, in the leading case of Hagan v. Platt, ${ }^{17}$ adopted the rule of apportionment enunciated in the English cases. The Hagan case involved facts substantially similar to those in the Moore case, the sale having yielded an amount slightly larger than the original investment, but much smaller than the aggregate total of principal plus unpaid interest. The New Jersey courts have consistently followed the Hagan case, ${ }^{18}$ and the law appears to be settled in that jurisdiction, however uncertain it may be in others.

In the dubious state of the law in New York, caused by the Hall case and others to be reviewed later in this discussion, those who favor the apportionment doctrine rely strongly upon the case of Meldon v. Devlin, ${ }^{19}$ the only case in which the New York Court of Appeals has indicated approval of the doctrine. In this case the trustees sold two lots upon which they originally held two mortgages, aggregating about $\$ 25,000$. In 1885 the mortgages were foreclosed, and the trustees bought in the property. In 1893 the surviving trustee sold it for a sum less than the principal and interest of the original mortgages. Judge Barrett, writing for the majority in the Appellate Division, approved the application of a rule of apportionment, saying:

14. The surrogate had earlier stated in the course of his opinion that it did not appear whether the life tenant had issue to take the remainder after her life interest terminated. After making the statement discussed above, he added that if the life tenant had issue who were remaindermen as to her share, they were not parties to this proceeding, and their rights could not be affected by this adjudication. Id. at $8 \mathrm{r}$.

15. In Matter of Marshall, 43 Misc. 238, 88 N. Y. Supp. 550 (Surr. Ct. 1904), a rule of apportionment was applied notwithstanding the fact that the investment was by the executors, not by the testator.

I6. Professor Bogert refers to it as a "rather unusual" case. 4 Bogert, TRUSTS AND TRUSTEES (I935) $\$ 820$, n. 30 .

I7. 48 N. J. Eq. 206, 21 Atl. 860 (Ch. I89I).

I8. In re Tuttle, 49 N. J. Eq. 259, 24 Atl. I (Prerog. 1892) ; Trenton Trust \& Safe Deposit Co. v. Donnelly, 65 N. J. Eq. Ir9, 55 Atl. 92 (Ch. I903); Equitable Trust Co. v. Swoboda, II3 N. J. Eq. 399, I67 At1. 525 (Ch. I933).

I9. 3I App. Div. I46, 52 N. Y. Supp. I72 (Ist Dep't I898), aff'd on opinion below, I67 N. Y. 573,60 N. E. III6 (IgOI). 
"It is well settled that when the interest upon mortgages is unpaid, and the premises are eventually sold, the sum received should be ratably apportioned between principal and income. (2 Lewin Trusts [Am. ed. I889], I228; In re Moore, 54 L. J. Ch. 432 ; Hagan v. Platt, 48 N. J. Eq. 206.) . This is not a case of devastavit; and cases like Cook $v$. Lozery (95 N. Y. I03) have no application." 20

Two justices in the Appellate Division dissented from this opinion on other grounds. Subsequently, the Court of Appeals affirmed per curiam the decision of the Appellate Division on Judge Barrett's majority opinion. ${ }^{21}$

If emphasis were needed to establish more firmly the doctrine of the Meldon case in New York law, it was given by Surrogate Silkman in Matter of Marshall, ${ }^{22}$ which contains a discussion in many respects the clearest and fullest to be found on the subject in the New York decisions. ${ }^{23}$ Interestingly enough, the surrogate's opinion discloses the fact that the Meldon case was not cited by counsel for either party. In any event, the Marshall decision has had the effect of gaining for the Meldon case a degree of importance and general recognition which it might not otherwise have achieved. ${ }^{24}$

For more than a decade the rule established by the Meldon and Marshall cases was regarded as settled law in New York,, ${ }^{25}$ and even thereafter the serenity of practitioners and fiduciaries was not disturbed by a case which, had it obtained more widespread notice, might have caused them serious concern. In Matter of Brooklyn Trust Co. (Weaver Estate), ${ }^{26}$ the surrogate's opinion was concerned only with the question of the allocation of carrying vote.

20. 3 I App. Div, at I58, 53 N. Y. Supp. at r8o. vote.

21. I67 N. Y. 573,60 N. E. III6 (IgOr). Two judges in the Court of Appeals did not

22. 43 Misc. 238, 88 N. Y. Supp. 550 (Surr. Ct. 1904).

23. Professor Bogert states that in some cases "it is held that trust capital must be replaced first, income second, and that the balance, if any, must go to trust capital." $\mathrm{He}$ cites, among other cases in support of this proposition, the Marshall case. 4 BOGRRT, TRUSTS AND TRUSTEEs (1935) § 820. This is misleading, however, for the Marshall case approves a rule of apportionment which would give to the life tenant a proportionate share of the proceeds of sale, without preference either to the life tenant or to the remainderman as to priority of distribution. In the Marshall case it appeared that the life tenants were satisfied to accept the amount remaining after the original investment was restored, but it is clear that they might have insisted upon a proportionate distribution, in which case there would not have been a complete restoration of principal.

24. Surrogate Silkman attributes the omission of counsel to cite a decision so authoritative, to the fact that "the compilers of our working digests seem to have failed to appreciate the importance of the rule established." 43 Misc. $238,245,88$ N. Y. Supp. 550, 554 (Surr. Ct. I904).

25. In Matter of Olmstead, 52 App. Div. 515, 66 N. Y. Supp. 212 (Ist Dep’t I900), aff'd without opinion, I64 N. X. 57I, $58 \mathrm{~N}$. E. 1090 (1900), the trustee invested in a mortgage which it became necessary to foreclose. After considerable delay the property was sold, leaving a large deficiency. The expenses of foreclosure and the taxes were charged against the estate by the trustee, but it does not appear from the report whether there was any apportionment of the proceeds of sale.

26. 92 Misc. 674, I57 N. Y. Supp. 547 (Surr. Ct. I915), aff'd zerthont opinion, I73 App. Div. 948 , I58 N. Y. Supp. IIo9 (2d Dep't I9I6), 219 N. Y. 565, II4 N. E. IO6I (I9I6). 
charges where the trustee had foreclosed a trust mortgage and still held title to the property. Certain buildings on the property held by the trustee were damaged by fire, and the trustee took, in place of the buildings, moneys received under an insurance policy. The trustee received further moneys upon the sale of the properties. There is no mention in the surrogate's opinion as to what disposition was, or should be, made either of the proceeds received under the insurance policy or of those received from the sale of the properties. In the memorandum in the Court of Appeals ${ }^{27}$ it appears, however, that the surrogate had overruled an objection to the trustee's accounts, made by the life tenant on the ground that the proceeds of the fire insurance policy should have been apportioned between principal and income. The Court of Appeals, as the Appellate Division had done, affirmed without opinion the decree of the surrogate, refusing to apportion these proceeds.

Since there was no opinion in either of the appellate courts, and since the surrogate's opinion did not discuss the question of apportionment, this case attracted little attention among lawyers and fiduciaries, and even now, because of the very character of the decisions, there is a tendency to discount it as an authoritative one. Furthermore, as will be pointed out in the discussion of carrying charges, the surrogate seems to have based his opinion concerning that point largely upon cases in the field of trusts of unproductive real property, and to have ignored cases which involved the very points in issue. ${ }^{28}$ And although the record in both appellate courts discloses that the surrogate denied apportionment both of the proceeds from the sale and from the fire insurance policy, ${ }^{29}$ the memorandum in the Court of Appeals makes no mention of a contention by the life tenant that there should have been an apportionment of the proceeds from the sale. This may indicate that the court's attention was centered upon the proceeds from the policy, and that full consideration was not given to the fact that proceeds resulting from the ultimate sale following foreclosure of a trust mortgage were also to be distributed.

Whatever its implications may be, the Brooklyn Trust Co. case had little immediate effect upon trust administration. Lawyers generally, as well as those courts which were faced squarely with the problem, continued to follow

27. 219 N. Y. 565, II4 N. E. I06I (I9I6).

28. The appellant, both in the Appellate Division and in the Court of Appeals, cited but one case in his entire brief, and this a case which dealt with the problem only by analogyLawrence v. Littlefield, 215 N. Y. 56r, IOg N. E. 6II (IgI5) - a case involving a trust of unproductive real estate, accompanied by an imperative power of sale. The Meldon and the Marshall cases (supra notes I9, 22), which were clear authority for the appellant's position, were not mentioned in his brief.

29. The following quotation from the respondent's brief, in both appellate courts, is of interest: "We do not think that the question of the apportionment between principal and income of the amount received by the Trustee for the fire loss and sale of the property can be seriously argued and therefore, we shall not discuss it on our brief." Italics added. 
a rule of apportionment. ${ }^{30}$ Although the question was not frequently litigated, other jurisdictions adhered to this theory. ${ }^{31}$

Ignored in practice and as precedent, the Brooklyn Trust Co. case seemed destined to ultimate characterization as a "sporadic" one. The doubt which it caused has been recently revived, however, in a manner especially alarming to New York fiduciaries who had come to regard the doctrine of apportionment as a settled one in this field. The New York Appellate Division in the Second Judicial Department, silent for nearly twenty years on the subject, has reaffirmed in Matter of Chapal ${ }^{32}$ its position taken in the Brooklyn Trust Co. case. In the Chapal case, $\$ 20,000$ was invested by the executors in mortgages which were later turned over to the trustees. Two of the mortgagors defaulted, whereupon the trustees foreclosed the mortgages and bid in the properties at the foreclosure sale. The trustees advanced all of the carrying charges. It appeared that one of the foreclosed properties produced no income, while the other produced a surplus over carrying charges. The trustees sought instructions as to what should be done with the proceeds if the properties were sold. The surrogate of Nassau County held that when any particular parcel was sold, "the proceeds should be properly allocated as between principal and income." The opinion in the Appellate Division is concerned for the most part with the allocation of carrying charges, but at the conclusion of the opinion, and without citation of authorities, it is stated that the decree of the surrogate providing that the proceeds of sale be apportioned between principal and income should be modified to provide that the proceeds of sale be added to principal. Unfortunately, most of the attention of court and counsel appears to have been directed to the question of allocation of carrying charges, and, as in the Brooklyn Trust Co. case, the problem

30. In re Myers' Estate, I6r N. Y. Supp. IIIr (N. Y. Surr. Ct. IgI6) ; Matter of Chapel, N. Y. L. J., Dec. 23, I924 (N. Y. Surr. Ct. I924); Matter of Jackson, I35 Misc. 329, 239 N. Y. Supp. 362 (Surr. Ct. I929), aff'd, 232 App. Div. 425, 250 N. Y. Supp. 324 (2d Dep't I93I), rev'd on other grounds, 258 N. Y. $28 \mathrm{I}$, I79 N. E. 496 (I932), reargument denied, 258 N. Y. 6Io, I80 N. E. 354 (I932); Matter of Ely, N. Y. L. J., Nov. 3, I933, at I608 (N. Y. Surr. Ct. I933).

In Furniss v. Cruikshank, I9I App. Div. 450, I8I N. Y. Supp. 522 (Ist Dep't I920), snodified on other grounds, 230 N. Y. 495,130 N. E. 625 (I92I), 23I N. Y. 550, 132 N. E. 884 (I92I), the loss on a mortgage investment was $\$ 6,937.74$. The trustee charged this loss to capital. It does not appear from the report that any apportionment of the proceeds of sale took place or that any was contemplated. That the case is not to be regarded as authority against apportionment, however, is indicated by the following excerpt from Farb, Distribution of Proceeds on Sale of Properties under Foreclosed Mortgages (I933) 58 Trust ConPANIES 245, 249: "An examination of the case on appeal [Furniss v. Cruikshank] shows that no claim was made for the apportionment between principal and income of the proceeds of sale. Had such apportionment been made, it is evident that the loss sustained by the principal account would have been greater. The referee who was appointed to take and state the account of the trustees stated in his report:

"The life tenants did not complain of their loss of income and have not asked to apportion the proceeds of sale between principal and income as might be done."

3I. Wallace v. Wallace, 90 S. C. 6I, 72 S. E. 553 (I9Ir); In re Hubbuck, [1896] I Ch. 754; In re Alston, [Igor] 2 Ch. 584; In re Atkinson, [1904] 2 Ch. 160; Stewart v. Kingsale, [1902] I Ir. 496; In re Plumb, 27 Ont. 501 (I896).

32. 280 N. Y. Supp. 8II, 245 App. Div. 8I8 (2d Dep't I935). This case is also reported in N. Y. L. J. July 2 , I935, at 21 , sub nom. Matter of Olvany. 
of apportionment seems not to have received the full consideration which it merited.

To summarize, it may be said that as far as judicial authority is concerned, in those jurisdictions.outside of New York where the question has arisen, the cases have consistently favored apportionment. The majority of cases in New York have likewise reached this result, but the Brooklyn Trust Co. and Chapal cases cause uneasiness to those whose duty it is to advise fiduciaries. Yet in theory and practice there would seem to be no reasonable objection to the rule. ${ }^{33}$ It is obviously unfair that one party should bear the entire loss, particularly since the life tenant is usually the primary object of the settlor's or testator's bounty. In some jurisdictions the rule has been followed for over half a century, and whatever variants there may be in its practical application, it has been found to achieve a uniformly equitable result.

\section{B. Apportionment When Sale Results in Profit}

Even those courts which have unhesitatingly adopted a rule of apportionment in cases involving a sale which resulted in loss have not been wholly in accord on the question whether there should be an apportionment when the sale results in profit. The principle that any increase in the value of real estate should go to corpus is well established in the law of trusts. ${ }^{34}$ Some courts and judges have regarded this principle as controlling the disposition of surplus over and above the original investment plus unpaid interest, etc. ${ }^{35}$ Other courts have felt that the purchase of real estate by the trustee represents an investment of both principal and income, and that consequently each should share in any profit resulting from the ultimate sale. The litigated cases involving such a profit are few, but they clearly exhibit the conflicting points of view.

The first case on the subject appears to be an early New York one, Schoonmaker $v$. Van $W y c k .^{36}$ A testatrix left one-third of her estate to be invested in bonds and mortgages on real estate and to be held in trust for one Isaac Van Wyck during his life, with remainder over. The executors invested in a mortgage which it became necessary to foreclose. Unable to find a purchaser, the executors themselves acquired the title at the foreclosure sale.

33. See Farb, supra note 30; Newhall, Apportionment of Losses on Mortgage Foreclosures (Aug. I933) I8 MASS. L. Q. 81; 2 JARIIAN, WIILS (7th ed. I930) I205; 2 PERRY, TRUSTS AND TRUSTEES ( 7 th ed. r929) $\$ 548 \mathrm{c}$.

34. First National Bank v. Lee, 23 Ky. L. Rep. I897, 66 S. W. 413 (I902); First National Bank v. Mulholland, I23 Miss. I3, 85 So. III (I920) ; Outcault v. Appleby, 36 N. J. Eq. 73 (Ch. I882) ; 2 PeRry, TRUSTS AND TrUStees (7th ed. 1929) $\$ 547$; see Note (I921) I3 A. L. R. I004, IOI7.

35. Farb, supra note 30 , at 247, takes this position. Dodge, Estame Administration and Accounting (I932), Supp. No. I (1933) 293, is also of this opinion. Contra: RestateMIENT, TRUSTS (I935) \$24I, comment $c$.

36. 3I Barb. 457 (N. Y. Sup. Ct. I860); see (I925) 23 Micr. L. REv. 431. 
They held the premises for about fifteen years, and then disposed of them at a price which was nearly $\$ 8,000$ more than the amount paid at the foreclosure sale. The court held, in substance, that out of the proceeds there should first be restored the amount of the original investment; that secondly unpaid interest should be satisfied; and that finally whatever remained of the fund should be allocated to principal. The effect of the decision is to give to principal all of the profit remaining after replacing the original principal and accrued interest.

An apparently similar result was reached some years later by a New Jersey court in Parker $v$. Johnson. ${ }^{\mathbf{3 7}}$ In this case the trustee held a defaulted trust mortgage. He foreclosed it and bought in the real estate. Later he sold the property and realized about $\$ 1,700$ more than the amount of the principal and interest on the investment and of costs, carrying charges, and expenses. There were three other pieces of property, of which the trustee was in possession, either as mortgagee or under a foreclosure, on which the trust fund might incur a loss. The life tenant asked that the $\$ 1,700$ be applied to the payment of arrears of interest on suspended investments. The court denied that this sum was income to which the life tenant was entitled, and held that it was the duty of a trustee to use the profit on one investment to make up the loss on others. ${ }^{38}$ The language of Chancellor Runyon is of interest, albeit a bit ambiguous:

"There are no arrears on the investment which was made on the Orange Street property. They have all been paid out of the proceeds of the sale of the property by the trustee. There are arrears of interest on the suspended investments, and the question is whether the life tenant is entitled to be paid those arrears out of the profit on the sale, or whether the profit should be held to make up a possible if not probable deficiency in the principal through losses on the suspended investments. The profit is not income. It was made by the trustee in the process of converting the investment, and, like a premium realized on the sale of government bonds in which the fund might be invested, it belongs to the fund. The trustee in this case is to keep the fund invested, and the tenant for life is entitled to the interest. It is clearly the duty of the trustee to apply the profits on one investment to making up the losses on others." 39

37. 37 N. J. Eq. 366 (Ch. I883).

38. In Parker v. Seeley, 56 N. J. Eq. Iro, 38 Atl. 280 (Ch. I897) $\times$ although the court reached a substantially contrary result, it attempted to distinguish the case of Parker $v$. Johnson on the ground that in the Johnson case the trustee was ordered by the court to retain the surplus, and not to apply it to either principal or interest until it appeared whether or not there might be a loss on some of the other investments held under the same trust. The court in the Seeley case therefore argued that the Johnson case was not direct authority for the proposition that all of the profit should go to corpus. It added parenthetically that the court in the Johnson case did not have before it all of the authorities on the question. Despite this attempted distinction, the Johnson case is generally cited for the proposition that profit should go to corpus rather than be apportioned. See 4 BOGERT, TrUSTS AND TRUSTEES (I935) \$820; Equitable Trust Co. v. Swoboda, I I3 N. J. Eq. 399, 40I, I67 Atl. 525, 526 (Ch. I933).

39. 37 N. J. Eq. at 368 ( 1883 ). Italics added. 
The doctrine of Parker $v$. Johnson has been reiterated by way of dictum in a recent New Jersey case. ${ }^{40}$

In Parker $v$. Johnson the life tenant might have been successful if, instead of contending that the surplus should be applied to arrears of interest on other investments, he had urged that this fund should be apportioned between the respective parties. Another instance in which a life tenant failed to avail himself of his best argument for obtaining a share of the surplus is found in the Ohio case of Willis $v$. Holcomb. ${ }^{41}$ Here a part of the trust estate consisted of a mortgage. The mortgagor having defaulted in interest, an action was brought to foreclose the mortgage. The trustee found it necessary to purchase the land at the foreclosure sale in order to protect the trust estate. At the time the case was decided, the trustee was still in possession, and the property had greatly increased in value. The life tenant brought a suit to compel the trustee to sell the property and, after paying to the life tenant the surplus over the original investment, to reinvest the proceeds. It appeared that the life tenant had been in possession of the real estate and received rents and profits therefrom. The court accordingly held that since the life tenant had accepted the benefits of the land in lieu of the interest that he would have received on the investment, he could not demand a further amount equaling what the fund would have earned had it been at interest. The court held, however, that the life tenant was entitled to receive, out of the proceeds of sale, the difference by which the amount of interest that the fund would have earned had it been kept invested under the terms of the will exceeded the amount he had actually received in the form of rents and profits from the land. Our present interest, however, is chiefly with the distribution of the funds which was ordered by the court. The court directed that out of the proceeds of sale there should be taken, first, an amount equal to the original trust fund; and secondly, the amount, if any, which the life tenant had not estopped himself from claiming by reason of his acceptance of the rents and profits. Any balance remaining, the court held, should be added to the principal. As in the Johnson case, the life tenant did not specifically ask for an apportionment of the profit. But the case, as it stands, must be taken as authority for the proposition that a profit resulting from the ultimate sale should be allocated to corpus.

The courts of New Jersey, where the problem of apportionment seems to have arisen more often than in any other jurisdiction, have been unable to agree upon a uniform rule of distribution, where the ultimate sale resulted in profit. Several years after Parker $v$. Johnson was decided, the New Jersey Court of Chancery was again confronted with the question of the disposition of a profit resulting from the sale of foreclosed trust properties. In 1933).

40. See Equitable Trust Co. v. Swoboda, II3 N. J. Eq. 399, 40I, I67 At1. 525, 526 (Ch.

4I. 83 Ohio St. 254,94 N. E. 486 (IgII). 
Parker v. Seeley, ${ }^{42}$ it was held that the profit should be divided between the life tenant and the remainderman in the proportion which the unpaid interest bore to the principal invested in the mortgage. This case is of especial significance because it introduces for the first time into the case law in this field the concept of the purchase of the real estate by the trustee as an investment of both capital and income. Vice-Chancellor Pitney, in an illuminating opinion, also declared that the same rule which governs the apportionment of a loss resulting from the foreclosure of a trust mortgage should control the disposition of a profit arising under these circumstances. His language is as follows :

"It will be observed that the real estate was purchased with the funds of the estate, consisting partly of principal and partly of interest; the principal belonging to the remainder-man, and the interest to the tenant for life. This subject was dealt with, in the case of a loss arising under such circumstances, in the case of Hagan v. Platt, 48 N. J. Eq. 206, 2 I Atl. 860; and the doctrine there laid down was followed and applied by the chancellor in Tuttle's Case, 49 N. J. Eq. 262, 24 Atl. I. The rule so established is that in case of a loss the deficiency is to be divided between the tenant for life and the remainder-man in the proportion which the principal represented by the investment bears to the interest which was in arrear, and also represented by the investment. And it seems to me that the same principle applies to the case where a profit, instead of a loss, arises. . . . The consideration which seems to control is that the property purchased represents both principal and interest, and its growth in value is due to both sources. . . ." 43

The rule of Parker $v$. Seeley has been upheld in two subsequent New Jersey cases ${ }^{44}$ but, as previously indicated, a dictum in the most recent case ${ }^{45}$ on the subject reverts to the earlier position of allocating all profit to corpus. ${ }^{46}$

42. 56 N. J. Eq. I10, 38 Atl. 280 (Ch. I897).

43. Id. at I $14,38 \mathrm{Atl}$. at $28 \mathrm{r}$. Italics added.

44. McCoy v. McCloskey, 94 N. J. Eq. 60, II7 At1. 473 (Ch. I922) ; Skinner v. Boyd, 98 N. J. Eq. 55, I30 Atl. 22 (Ch. 1925), aff'd, roo N. J. Eq. 355, I34 At1. 919 (I926). I933).

45. See Equitable Trust Co. v. Swoboda, II3 N. J. Eq. 399, 40r, I67 Atl. 525, 526 (Ch.

46. New Jersey is also one of the few jurisdictions which have passed on the question whether the fact that the mortgage was a purchase money mortgage should make any difference in the applicability of the rules herein discussed. This question arose in Burnett $\mathrm{v}$. Witschief, 96 N. J. Eq. 71, I26 Atl. 23 (Ch. 1924), (1925) 23 MrCr. L. Rev. 43I. In this case a parcel of real estate forming a part of the corpus of a trust for the testator's widow was sold under a power of sale. The executors accepted a purchase money mortgage in payment. Thereafter they foreclosed the mortgage and bought back the property to save the investment. Seven years later they again sold the property at an increase over the price of the first sale. The widow claimed that the increase should be apportioned between life tenant and remainderman, such apportionment to be based upon the sum of interest which would have accrued to her on the foreclosed mortgage if it had not been foreclosed, and the interest had been paid. The court held: ( 1 ) that the sale of the real estate under the power given in the will worked no conversion; (2) that the mortgage taken in payment remained realty in the hands of the executors, in trust for the life tenant and remainderman; (3) that the net yield of the property, whether from the mortgage or from the land itself, when held by the executor, in the form of rents and profits, belonged to the life tenant; (4) that the increased price of the second sale belonged to principal; (5) but that since the life tenant would have 
The argument for apportionment of profit is thus bottomed on the proposition that the foreclosed property represents an investment of both capital and unpaid interest. If at the time of foreclosure there is no interest in arrears, most authorities would doubtless agree that since there is no investment of income in the property, all profit should be added to principal. This was the result apparently reached in a New York case, Van Vleck v. Lounisbery. ${ }^{47}$ This case is complicated, however, by the fact that the life tenant received, in addition to the interest on the mortgage, the rents from the property during the time it was being held by the trustee. It is probable that the court, like the :Ohio court in Willis $v$. Holcomb, ${ }^{48}$ was influenced in its decision by some element of estoppel occasioned by the acceptance of rents. If, as in the Ohio case, there was a default in interest, the "estoppel" argument is not persuasive, since the life tenant has an investment in the property, and the rents should constitute only a pro tanto deduction from his share of the ultimate proceeds. On its peculiar facts, however, the $V$ an Vleck decision is one with which few would be disposed to quarrel. ${ }^{49}$

To recapitulate, although the decisions have been about equally divided on the question of apportionment of the proceeds of sale when a profit results,

had the rents from the land if the sale thad not taken place, and since she suffered a loss of income due to a default in interest on the mortgage, she should bet recompensed out of the final proceeds of sale to the extent of the amount of rents she would have received if the property had not been sold. The net income of the land for the period of default was to be determined from the average net yearly income during the possession of the life tenant and the executor.

This decision is in effect a holding that the normal rules of apportionment do not apply to a purchase money mortgage. It is not perceived why there should be any real distinction between the treatment of this type of mortgage and that of any other. The life tenant is entitled to the interest from the purchase money mortgage, whatever its duration may be. If there is a default in the interest, the life tenant has sustained a loss as genuine as that in any other case. The purchase of the property at the foreclosure sale again represents an investment which includes the unpaid interest. It is true that if there had been an outright sale of the property, the life tenant would not have been entitled to share in the proceeds in the absence of facts calling for an application of the doctrine of equitable conversion, but the fact remains that the life tenant has suffered a loss in interest from the mortgage, and the loss so resulting should not be borne entirely by him.

Apparently contrary to the Burnett case is McCoy v. McCloskey, 94 N. J. Eq. 6o, II7 At1. 473 (Ch. Ig22), wherein it was said that if a purchase money mortgage is to be regarded as merged in the legal title upon the foreclosure sale, then upon a sale at a profit, the life tenant would be entitled to a proportionate share of the proceeds. $C f$. Matter of Wardman, 154 Misc. 255, 276 N. Y. Supp. 778 (Surr. Ct. 1935), wherein the rules as to the allocation of carrying charges upon the foreclosure of a trust mortgage were applied without reference to the fact that the mortgage involved was a purchase money mortgage.

47. 34 Hun 569 (N. Y. I885).

48. 83 Ohio St. 254, 94 N. E. 486 (IgII).

49. A difficult question would be presented by a case in which there was no default in interest at the time of foreclosure, but in which the trustee carried the foreclosed property for a long perind of time with little or no income to the life tenant in the interim. Under the theory advanced by Vice-chancellor Pitney, the right of the life tenant to share in the proceeds of the ultimate sale is based upon the fact that the trustee's bid at the foreclosure sale represents both principal and unpaid interest. In the hypothetical case suggested, there would obiously be no investment of income at the outset, but it might be argued that ultimately income would be represented in the property, and that in any event all of the equities in favor of the life tenant are present. Certainly this would be true in the case of a sale resulting in loss, and it will be recalled that apportionment was an equitable doctrine even before the "investment" theory was developed. 
the better view would seem to be that there should be an apportionment of the surplus. This does not do violence to the usual rule that an increase in the value of real estate should go to corpus, since the cases which have established this general rule are not cases in which the life tenant had any direct interest or investment in the property itself. If, as Vice-Chancellor Pitney has declared, the growth in value is due to both principal and interest, each should have a proportionate share in the proceeds if the joint venture proves successful. ${ }^{50}$

\section{Basis on Which Apportionment of Proceeds Should Be Made}

Although the cases outside of New York are fairly uniform in directing an apportionment of the proceeds of sale, at least in the event of a loss, there has not been as complete agreement on the method of apportionment. In the earliest case in which a loss was involved, Roosevelt $v$. Roosevelt, ${ }^{51}$ the court employed what might be called the recapitalization method. Under this method a sum is ascertained which would produce, together with interest at the rate to which the life tenant is entitled, the amount received on the final sale. This sum is distributed to the remainderman, and the difference between it and the amount actually received is given to the life tenant. This formula for apportionment was derived from a similar one employed in the English case of $\operatorname{Cox} v$. Cox $^{52}$

The English case of In re Moore ${ }^{53}$ approached the solution somewhat differently. It will be recalled that in this case the original investment was

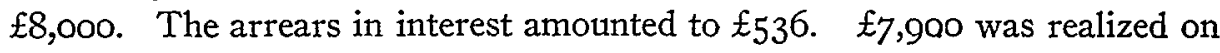

50. One further profit case, In re Park's Estate, I73 Pa. I90, 33 Atl. 884 (I896), deserves mention. Here a testator left his estate to his executors in trust to receive and collect the rents of the real estate and the income and profits of the personal estate, and after deducting taxes and certain annuities, to pay the residue of the net income to his daughter for her life, with remainder over. The exectutors invested part of the estate in mortgages, which were subsequently foreclosed. They bid in the property for the amounts of the mortgages in order to protect the estate. At a subsequent sale of the properties a profit resulted. The court held that after restoring the amount of the original investment, the residue belonged to the life tenant. The result in this case appears to be due to the language of the will, which stated that all income and profits of the personal estate should go to the life tenant. The court reasoned that by equitable conversion the foreclosed real estate remained personalty. and that as a consequence the profit on the sale was "income and profits" of the personal estate. 4 BoGERT, TRUSTS AND TRUSTEES (I935) $\$ 820$, states that cases granting such a profit to the life tenant as income seem unexplainable, but that the Park case may be rationalized on the basis of the testator's express intent.

51. 5 Redf. Surr. 264 (N. Y. Surr. Ct. I88I). It is interesting to note that Surrogate Calvin apparently first considered applying the rule now known as the "Meldon rule," but for some reason rejected it. He said at page 266: "The natural first impression, in considering this case, was to ascertain the amount of loss of principal and of interest, by a computation of interest upon the amount due to the decedent at his death upon the respective obligations referred to, deduct the amount realized from the principal and interest thus computed, and charge to the respective beneficiaries the amount of the loss, in proportion to their interests, respectively, so ascertained. But a moment's reflection showed that that was an erroneous basis, for the reason that the amount due at the death was not realized, and therefore was not a proper statement of the remainder-man's interest. Hence, it becomes necessary to adopt some rule, by which it can be ascertained what the equitable proportion of the loss sustained is."

52. L. R. 8 Eq. 343 (I869).

53. 54 L. J. Ch. (N. S.) 432 (I885). 
the sale. The court held that the $\mathfrak{x}_{7,900}$ should be apportioned in the ratio which $f_{8,000}$ bore to $\mathfrak{f}_{53} 6$. This method was adopted in the well-known New Jersey case of Hagan $v$. Platt, ${ }^{54}$ and it was introduced into the law of New York by the case of Meldon $v$. Devlin.55 The language of these cases is to the effect that the fund should be apportioned in the ratio of the aggregate principal to the whole unpaid interest. The use of the term, "ratio", is somewhat confusing, in the practical application of the formula, since it implies a direct fractional relation between aggregate principal and the whole unpaid interest. What actually happens may best be illustrated symbolically. Let $P$ represent the aggregate principal, $i$ the unpaid interest, and $C$ the proceeds; let the life tenant's share of the proceeds be represented by $x$ and the remainderman's share by $X$. The proper solutions will then be:

$$
\frac{i}{P+i}=\frac{x}{C} \text {, and } \frac{P}{P+i}=\frac{X}{C} \cdot{ }^{56}
$$

The difference between the Roosevelt and Meldon formulas is not so great as might be supposed. Indeed, an application of either formula would arrive at the same result, if the same rate of interest were taken in computing the amount due the life tenant in each formula. It is only when a different rate of interest is employed that it becomes important which formula is used. The distinction is not academic, for some courts, as will be shown later in the course of this discussion, have allowed to the life tenant the mortgage rate of interest throughout the entire period of default, others have allowed the mortgage rate until the date of foreclosure and the prevailing rate thereafter, while still others have allowed only the prevailing rate throughout the period in question. The Roosevelt formula appears to have had no following in the cases either in New York or elsewhere, ${ }^{57}$ and the custom of trustees

54. 48 N. J. Eq. 206, 2 I At1. 860 (Ch. I89r).

55. 3I App. Div. I46 (Ist Dep't I898), aff'd on opinion below, I67 N. Y. 573 (IgoI).

56. That this is the formula actually applied by the courts is illustrated by the case of Hagan v. Platt, 48 N. J. Eq. 206, 2I At1. 860 (Ch. I89I). In this case, the principal involved was $\$ 1,200$, the unpaid interest $\$ 1,252$, and the proceeds $\$ 1,267.94$. The court accordingly distributed $\$ 620.52$ to principal and $\$ 647.42$ to income.

57. The Uniform Principal and Income Act [see 9 U. L. A. (Supp. I934) Ir4; Ore. Laws I93I, c. 37I] posits a rule which is in some ways suggestive of the Roosevelt formula. The Uniform Act does not draw any distinction between unproductive property held by the trustee as a part of the original trust estate, and unproductive property held by the trustee as the result of the foreclosure of a trust mortgage. This is probably due to the fact that the Uniform Act does not require an intent on the part of the testator to effect an equitable conversion in order to bring about an apportionment of the proceeds of the sale of unproductive property. See Brandis, Trust Administration: Apportionment of Proceeds of Sale of Unproductive Land and of Expenses (193I) 9 N. C. L. REv. I27; Note (1930) 40 Y YLE L. J. 275 .

Section II of the Uniform Act provides that the amount to be credited to income shall be the difference between the net proceeds received from the property and the amount which, had it been placed at simple interest at the rate of five per cent per ammum, would (with the interest) have produced the net proceeds. The section states in part: "(2) Such income shall be the difference between the net proceeds received from the property and the amount which, had it been placed at simple interest at the rate of five per centum per annnm for the 
has been to utilize the Meldon formula whenever apportionment becomes necessary.

The rule of Hagan $v$. Platt and Meldon $v$. Devlin left two questions somewhat uncertain: (I) What is included within the term, "aggregate principal"? (2) On what basis is the "whole unpaid interest" to be computed?

In the leading and widely known case of Matter of Marshall,, ${ }^{58}$ Surrogate Silkman attempted an answer to the first of these questions. In this case the executors invested $\$ 15,000$ and $\$ 3,000$ respectively in two bonds and mortgages. They purchased the realty securing the former in 1879 , carried it until 1903, and then sold it for $\$ 54,500$. The costs of foreclosure, carrying charges, and other incidental expenses amounted in all to $\$ 16,174.33$. The executors purchased the property securing the $\$ 3,000$ mortgage in 1875 , carried it until 1899 , and sold it for the net sum of $\$ 9,405$. The cost of carrying the property amounted to $\$ 2$, I08.I5. The surrogate held that the method used in the Meldon case should be employed, namely, that the proceeds should be divided in the ratio of the aggregate principal to the whole unpaid interest. The aggregate principal, he declared, was "the principal locked up in the property, that is, the original amount of the mortgage and the various amounts of principal paid out for taxes, assessments, etc., from time to time." 59 Later in the course of his opinion, he added the following explanatory remarks :

"The amount of the foreclosed mortgage, together with the expense incurred for the foreclosure, the carrying charges, and the amount of the loss of income suffered, should constitute one common account, and upon the liquidation of the account by sale of the property taken in, the interests are to be adjusted and each party, life beneficiary and remainderman, is to get "exactly his own, so far as it is possible to ascertain." "Bo

It is clear, then, that under this decision the "aggregate principal" locked up in the investment includes the original amount of the mortgage, the expenses

period during which the change was delayed, would have produced the net proceeds at the time of change, but in no event shall such income be more than the amount by which the net proceeds exceed the fair inventory value of the property or in default thereof its market value at the time the principal was established or its cost where purchased later." This rule follows in a general way the formula employed in the Roosevelt and Cox cases but differs in two important respects. (I) It arbitrarily fixes the rate of interest at five per cent, instead of leaving the rate of interest to vary with the prevailing rate for investments generally. (2) It has an additional limitation in that the income is in no event to exceed the difference between the net proceeds of the sale and the fair inventory value of the property, or in default thereof, its cost where acquired by purchase.

In trusts of unproductive realty accompanied by a mandatory power of sale, a formula of apportionment similar to that applied in the Roosevelt case is used (see discussion supra lnote 6 ), but of course in such cases no other interest rate than the prevailing one could be employed.

58. 43 Misc. 238,88 N. Y. Supp. 550 (Surr. Ct. I904).

59. Id. at $24 \mathrm{I}, 88 \mathrm{~N}$. Y. Supp. at 552 .

60. Id. at $243,88 \mathrm{~N}$. Y. Supp. at 553 . 
of foreclosure, and the amounts paid for carrying charges during the period of ownership. ${ }^{61}$

The decision was a novel one in that apparently it had not been considered previously that anything more than the original investment was to be regarded as principal. In Meldon $v$. Devlin only the original investment in the mortgages appears to have been taken as principal, the carrying charges and expenses having been paid out of income from other parts of the trust estate. In the recent case of Matter of Jackson ${ }^{62}$ no mention is made in the opinion of the expenses and carrying charges, and the statement by the court of the computation to be followed indicates that the aggregate principal included nothing more than the amount of the original investment. On the other hand, an examination of the record in another New York decision, In re Myers' Estate, ${ }^{63}$ indicates that the rules laid down in the Marshall case were followed. No other decisions, either in New York or in other jurisdictions, have been found indicating whether foreclosure expenses and carrying charges should be included in the aggregate principal, although the practice in allocating carrying charges in New Jersey would indicate that there, at least, the aggregate principal would not include these items. ${ }^{64}$

The question of what constitutes the "whole unpaid interest" has also failed to receive the full consideration which it merits. The problem is in reality a twofold one, involving: (I) the rate which should be adopted during the period of default under the mortgage up to the date of the acquisition of title, and (2) the rate which should be adopted during the period of ownership by the trustee; although some courts have not made any distinction between these two periods. The majority of cases appear to have allowed interest at some rate or other from the date of the first default until the date of the ultimate sale. ${ }^{65}$ The case of Matter of Jackson is again of significance in this regard, however. In the Jackson case interest was allowed only from

6r. Whether rents received during the carrying period should be deducted from the amount calculated as aggregate principal in the ratio taken is a question which will receive consideration later in this discussion.

62. I35 Misc. 329, 239 N. Y. Supp. 362 (Surr. Ct. r929), aff'd, 232 App. Div. 425, 250 N. Y. Supp. 324 (2d Dep't 193I), ren'd on other grounds, 258 N. Y. 28I, 179 N. E. 496 (1932), reargninent denied, 258 N. Y. 6ro, I80 N. E. 354 (1932).

63. I6r N. Y. Supp. IIII (Surr. Ct. I9I6).

64. Cf. Trenton Trust \& Safe Deposit Co. v. Donnelly, 65 N. J. Eq. II9, 55 Atl. 92 (Ch. I903); Equitable Trust Co. v. Swoboda, II3 N. J. Eq. 399, I67 Atl. 525 (Ch. I933). This question cuts so deeply into the problem of the disposition of carrying charges and other expenses incident to the acquisition of title that an opinion as to the advisability of the Marshall rule will be withheld until the matter of carrying charges is more exhaustively treated in the text.

65. This was true in the following cases: Roosevelt v. Roosevelt, 5 Redf. Surr. 264 (N. Y. Surr. Ct. I881) ; Meldon v. Devlin, 3 I App. Div. I46 (Ist Dep't I898), aff'd, I67 N. Y. 573 (IgOI) ; In re Myers' Estate, I6I N. Y. Supp. IIII (Surr. Ct. IgI6); Matter of Marshall, 43 Misc. 238,88 N. Y. Supp. 550 (Surr. Ct. I904) ; Hagan v. Platt, 48 N. J. Eq. 206, 21 Atl. 860 (Ch. I89r); In re Tuttle, 49 N. J. Eq. 259, 24 Atl. I (Prerog. I892) (interest after death of life tenant to date of sale added to principal for purposes of apportionment); Trenton Trust \& Safe Deposit Co. v. Donnelly, 65 N. J. Eq. rr9, 55 Atl. 92 (Ch. I903), UNIFORM PRINCIPAL AND INCOME ACT \$ II allows interest from the date of default until the date of the ultimate sale or the date when the proceeds of sale are received. 
the time of default until the date on which the trustee accepted a deed to save the expense of foreclosure. The trustee held the property for nearly two years thereafter, but no interest appears to have been allowed for that intervening period, although the court cites and purports to follow the rule of Meldon v. Devlin.

It is upon the rate of interest that most of the discussion in the cases centers. The courts in Roosevelt $v$. Roosevelt and Cox v. Cox allowed the prevailing rate of interest for investments generally, rather than the mortgage rate. ${ }^{6}$ In Meldon $v$. Devlin there appears no discussion of the rate of interest allowed, but an examination of the record on appeal reveals that the interest rate was scaled down, for the entire period of default, from the seven per cent allowed by the mortgage to six per cent. It does not appear whether any aspect of the usury laws entered into the decision, ${ }^{67}$ or whether the court was merely applying the prevailing rate of interest. In Matter of Marshall interest was allowed at the mortgage rate until the date of foreclosure, but the court felt that since interest rates had declined since the date of foreclosure, it would be inequitable to allow interest during the period of ownership by the trustee at a rate greater than the prevailing one. In Matter of Jackson it is uncertain what rate of interest was allowed, but it would seem that it was the mortgage rate until the date of acceptance of the deed in lieu of foreclosure. No interest was allowed after that date.

In the New Jersey cases no discussion is found of the rate of interest allowed, but it may be inferred that the mortgage rate was allowed even down to the date of the ultimate sale. No comment on the rate of interest to be allowed has been found in any other decisions.

In principle it would seem that the life tenant is entitled to the mortgage rate of interest until the time of foreclosure, and to the prevailing rate thereafter. To give the life tenant the mortgage rate until foreclosure simply allows him the amount which he has actually lost on the investment. This is the most readily ascertainable portion of the sum which, in the language of the cases, he risks in the joint venture. After foreclosure and the acquisition of title by the trustee, the mortgage rate can no longer be regarded as the controlling one; yet the life tenant continues to suffer a loss of income on the investment. The acquisition of title by the trustee cannot be considered

66. The UNIForm PRINCIPAL ANd InCONe ACT $\S$ II arbitrarily fixes the rate of interest at five per cent for all such periods of conversion.

67. Prior to January $\mathrm{r}, 188 \mathrm{o}$, the legal rate of interest in New York was seven per cent. By Chapter 538 of the Laws of 1879 , which took effect January I, I880, the rate was reduced to six per cent. But it was expressly enacted that nothing in the statute should be construed to affect any contract or obligation made before the passage of the act. See N. Y. Generar. Business Law (I909) $\$ 370$. The mortgages on the so-called "water lots" in the Meldon case were received by the trustees from the executor in 1872 , prior to the change in the usury law. The decision, on the other hand, came after the change, and although the statute had the aforementioned saving clause for contracts already in existence, the court might have been influenced by this change in the legal rate of interest. 
a reinvestment in real property, ${ }^{68}$ since under the principle of equitable conversion the real estate is looked upon as personalty. ${ }^{69}$ The conversion doctrine is, of course, an application of the well-known maxim that "equity regards as done that which ought to be done." It often happens, as in the case of a trust of unproductive realty with an imperative power of sale, ${ }^{70}$ that the life tenant is entitled to the immediate liquidation of an unprofitable investment and the reinvestment of the proceeds in an income-producing security. Yet frequently, because of conditions beyond the control of the trustee, immediate liquidation is impossible, and in fact the actual mutation does not take place for a considerable period of time. To protect the interests of the life tenant, equity regards as done that which ought to be done, and by virtue of the doctrine of equitable conversion declares the life tenant entitled to a share of the ultimate proceeds on the same basis as though the investment had been liquidated at the originally prescribed date. His share is computed at the rate prevailing for trust investments generally, as if the ultimate proceeds had in fact been reinvested at the time the liquidation was supposed to have been accomplished.

In the same manner, the purchase of the real estate by the trustee in the absence of other bidders is regarded as a delay in the liquidation, sufficient to warrant the application of the doctrine of equitable conversion. ${ }^{71}$ The real estate is therefore considered as that which it ought to be, namely, an investment in a productive security. On such an investment the life tenant should be given the rate of interest which he would receive if the investment were in fact what it is regarded as being. Under this analysis, the prevailing rate of interest for trust investments generally seems the only logical one to adopt for the period following foreclosure.

68. Matter of Marshall, 43 Misc, 238, 88 N. Y. Supp. 550 (Surr. Ct. I904) ; Furniss v. Cruikshank, I9I App. Div. 450, I8I N. Y. Supp. 522 (Ist Dep't I920), modified on other grounds, 230 N. Y. 495, 130 N. E. 625 (1921), 23 I N. Y. 550, r32 N. E. 884 (1921) ; Valentine v. Belden, 20 Hun 537 (N. Y. I88o) ; In re Park's Estate, I73 Pa. 190, 33 At1. 884 (I896); PeRRY, TRUSTS AND TRUSTEes ( 7 th ed. I929) $\$ 458$.

69. Matter of Marshall; In re Park's Estate; Valentine v. Belden, all supra note 68; Lockman v. Reilly, 95 N. Y. 64 (I884) ; Haberman v. Baker, I28 N. Y. 253,28 N. E. 370 (I89r) ; Wiederhold v. Koehler, I74 App. Div. I39, I60 N. Y. Supp. 927 (2d Dep't I916); PoMreroy, EQUiTy JURISPRUdence (4th ed. I9I8) \$ II59.

70. See discussion, supra note 6 .

7r. At this point there is not a complete analogy to the cases involving trusts of unproductive realty, since in those cases the intent of the testator to effect an equitable conversion is the sine qua non, although the intent may be inferred rather than express. The cases involving foreclosed trust properties, however, state that an equitable conversion is effected by the purchase of the property by the trustee, a development which the testator probably never contemplated. The requirement of a conversional intent has been questioned even in the field of trusts of unproductive realty [see Pound, J., in Matter of Jackson, 258 N. Y. 28I, 29I (I932) ], and the Uniform Principal and Income Act has dispensed with it as a prerequisite in this situation. In a trust of foreclosed realty, the conversion doctrine should not be based upon a supposed intent of the testator, nor is it so based by the cases. In this connection, BOGERT, TRUSTS AND TRUSTEEs (1935) \$ 820 , states: "There is no reason for allocating the loss directly to capital or to income. No question of intent of settlor or mortgagor is involved. In foreclosing the trustee was attempting to get back both interest and principal, and he succeeded only partially in his effort as to each." Italics added. 
In New York the Marshall case has drawn a large following of practitioners to the procedure just outlined. This is not a decision of a court of last resort, however, and in view of the earlier practice of allowing only the prevailing rate of interest for the entire period of default, the question may still be regarded as an open one in New York.

[To be concluded] 